\title{
Molecular Characterization of Coat Protein Gene of Blackgram Yellow Mosaic Virus (BGYMV) from Karnataka, India
}

\author{
G.U. Prema ${ }^{1 *}$ and K.T. Rangaswamy ${ }^{2}$ \\ ${ }^{1}$ Department of Plant Pathology, College of Agriculture, Vijaypur, UAS, Dharwad-586101 \\ ${ }^{2}$ Department of Plant Pathology, College of Agriculture, UAS, GKVK, Bangalore-560065 \\ *Corresponding author
}

\begin{tabular}{|c|}
\hline Keywords \\
\hline $\begin{array}{l}\text { Blackgram yellow } \\
\text { mosaic virus } \\
\text { (BGYMV), Coat } \\
\text { protein, } \\
\text { Characterization, } \\
\text { Phylogenetic } \\
\text { analysis, Nucleotide } \\
\text { sequence identity, } \\
\text { Amino acid identity }\end{array}$ \\
\hline Article Info \\
\hline $\begin{array}{l}\text { Accepted: } \\
17 \text { June } 2018 \\
\text { Available Online: } \\
\text { 10 July } 2018\end{array}$ \\
\hline
\end{tabular}

\section{A B S T R A C T}

Yellow mosaic virus is the most destructive disease of urdbean causing 5-100 per cent yield loss. BGYMV belongs to genus Begomovirus of the family Geminiviridae transmitted by white fly (Bemisia tabaci Gennadius). Polymerase chain reaction of yellow mosaic virus infecting blackgram samples using MYMV-CP-F/MYMV-CP-R primers amplified the expected product of size $1000 \mathrm{bp}$ from blackgram infected samples. Expected PCR products of size $1000 \mathrm{bp}$ obtained were cloned, sequenced and assembled. The total number of sequences obtained from blackgram yellow mosaic was 880 bp with $106 \mathrm{bp}$ of pre-coat protein region and $774 \mathrm{bp}$ of coat protein region of blackgram yellow mosaic virus. 257 amino acid lengths were predicted after translation of the nucleotide sequences. The cluster phylogram based on pairwise and multiple sequence alignment of the nucleotide sequence of the CP gene of 8 isolates of MYMV and 13 isolates of MYMIV indicated that the present isolate causing blackgram yellow mosaic virus formed cluster with other known isolates of MYMV. Sequence comparisons indicated that BGYMV has the highest nucleotide sequence identity of about 98.7 per cent, 98.4 per cent and 98.3 per cent and with MYMV-Namakkal:MoB [DQ865201.1]; MYMV-Madurai:SB [AJ421642.1], MYMV-Tamil Nadu:MB [AJ132575.1] and MYMV-Maharashtra:SB [AF314530.1] isolates, respectively. The nucleotide sequence identity of BGYMV with MYMV ranged from 94.4-98.7 per cent. The nucleotide sequence identity of BGYMV with MYMIV ranged between 79-80.7 per cent. When the deduced amino acid sequence of individual proteins were compared with those of other begomoviruses, the maximum homology of 99.2 per cent and 98.8 per cent was noticed with MYMV-Tamil Nadu:MB [AJ132575.1]; MYMV-Maharashtra:SB [AF314530.1] and MYMV-Namakkal:MoB [DQ865201.1]; MYMV-Madurai:SB [AJ421642.1] isolates, respectively. The deduced amino acid identities of BGYMV with Mungbean yellow mosaic virus revealed identities between 99.2-95.7 per cent. Deduced amino acid sequence comparison revealed that BGYMV revealed identities ranged from 84-85.9 per cent with Mungbean yellow mosaic India virus at amino acid level. The results of the present study revealed that coat protein gene of yellow mosaic virus infecting blackgram (BGYMV-Hebbal-Bangalore) is a Mungbean yellow mosaic virus (MYMV) but not Mungbean yellow mosaic India (MYMIV) virus and it is a variant of mungbean yellow mosaic virus since it showed 94.498.7 per cent identity at nucleotide level with other MYMV isolates. 


\section{Introduction}

Black gram or Urdbean (Vigna mungo L. Heper), is one of the important pulse crops grown throughout India. It is consumed in the form of dal (whole or split, husked and unhusked). This pulse legume is used for green manuring after picking the pods because of its characteristics to fix the atmospheric nitrogen. The plant with deep tap roots binds soil particles and helps in conservation of soil. Urdbean is widely cultivated in India, Myanmar, Srilanka, Thailand, the Philippines and Pakistan. In India, it is grown in states like Madhya Pradesh, Rajasthan, Uttar Pradesh, Orissa, Maharashtra, Andhra Pradesh, Tamil Nadu and Karnataka. In India, it is cultivated in an area of 32.15 lakh ha, with a production of 17.66 lakh tonnes and productivity of 549 $\mathrm{kg} / \mathrm{ha}$. The area under cultivation in Karnataka is 0.93 lakh ha, with a production of 0.35 lakh tones and productivity of $376 \mathrm{~kg} / \mathrm{ha}$ (Anon., 2012).

Several viruses infecting blackgram are yellow mosaic, leaf curl and leaf crinkle which are considered to be economically important resulting in crop losses (Biswas et al., 2012); Malathi and John, 2008; Qazi et al., 2007). Amongst viral diseases, yellow mosaic virus is the most destructive disease of urdbean causing 5-100 per cent yield loss (Nene, 1972; Singh et al., 1980; Rathi, 2002). The symptoms of blackgram yellow mosaic virus (BGYMV) firstly appear on young leaves in the form of yellow, diffused, round spots scattered on the leaf lamina. The infected leaves turn necrotic. The diseased plants usually mature later and bear relatively few flowers and pods. The pods are stunted and mostly remain immature but whenever seeds are formed they are small in size (Nene, 1972; Singh et al., 2002). BGYMV is not seedtransmitted, but numerous alternate hosts and the whitefly vector provides primary source of inoculum. This disease is transmitted by white fly (Bemisia tabaci Gennadius) and not by mechanical inoculation or by seed (Shad et al., 2005). BGYMV belongs to genus Begomovirus of the family Geminiviridae (Bos, 1999). The virus has geminate particles of size $20 \times 30 \mathrm{~nm}$ and single stranded DNA genome of $2.8 \mathrm{~Kb}$ (Roger Hull, 2004).

Two distinct begomoviruses, Mungbean yellow mosaic virus (MYMV) and Mungbean yellow mosaic India virus (MYMIV) were known to cause yellow mosaic disease on urdbean (Islam et al., 2012; Malathi and John, 2008; Ilyas et al., 2010; Islam et al., 2012; Shahid et al., 2012; Tsai et al., 2013). MYMV is confined to Thailand, Vietnam, and Peninsular region of India, whereas MYMIV occurs in Northern India, Pakistan, Nepal, Bangladesh and Indonesia. In this regard, an attempt has been made to characterize coat protein gene of YMV infecting urdbean and to confirm that Blackgram yellow mosaic virus (BGYMV) from Karnataka is an isolate or variant of Mungbean yellow mosaic virus (MYMV) rather than Mungbean Yellow Mosaic India Virus (MYMIV).

\section{Materials and Methods}

\section{DNA extraction}

Blackgram plants showing severe yellow mosaic and mottling symptoms were collected from field at the MRS, Hebbal, Bangalore, Karnataka (south India) during the 2012 (Plate 1). Samples from healthy plants were collected as controls.

The total genomic DNA was extracted from leaf tissues of healthy blackgram plants and YMV infected blackgram plants based on the method of Rouhibakhsh et al. (2008). One hundred and fifty milligrams of fresh YMV infected leaf tissues were ground with liquid nitrogen using sterile pestle and mortar. The whole ground sample was transferred into a 
fresh 1.5-ml eppendorf tube. $1500 \mu \mathrm{l}$ of prewarmed $\left(65^{\circ} \mathrm{C}\right)$ DNA extraction buffer was added to ground sample taken in $1.5-\mathrm{ml}$ eppendorf tube (added in situ just before DNA extraction). The whole crude sap was incubated for $30 \mathrm{~min}$ at $60^{\circ} \mathrm{C}$ in a water bath with occasional mixing. The supernatant $(750$ $\mu \mathrm{l})$ was transferred into a fresh $1.5-\mathrm{ml}$ effendorf tube and mixed with equal amount $(750 \mu \mathrm{l})$ of Phenol: chloroform: isoamyl alcohol (25: 24:1) by vertexing. The samples were then centrifuged at $13,000 \mathrm{rpm}$ for 10 min using micro centrifuge. The aqueous supernatant was collected in to a fresh $1.5-\mathrm{ml}$ eppendorf tube. The DNA was precipitated by mixing with $300 \mu \mathrm{l}$ of chilled isopropanol + $30 \mu \mathrm{l}$ of $7.5 \mathrm{M}$ Ammonium acetate by inversion. The tubes were centrifuged at $13,000 \mathrm{rpm}$ for $10 \mathrm{~min}$. The resulted pellet was washed with 70 per cent ethanol, dried in a vacuum drier for $10 \mathrm{~min}$ and re-suspended with $40 \mu \mathrm{l}$ of $\mathrm{T}_{10} \mathrm{E}_{0.1}$ buffer $(10 \mathrm{mM}$ Tris- $\mathrm{HCl}$ of $\mathrm{pH} 8.0$ and $0.1 \mathrm{mM}$ EDTA of $\mathrm{pH} 8.0$ ) and stored at $-20^{\circ} \mathrm{C}$. All the DNA extracts were further diluted from 1:10 to $1: 40$ in single distilled water (SDW) before using for PCR amplifications. The quality and quantity of DNA was assessed at $260 \mathrm{~nm}$ and $280 \mathrm{~nm}$ using UV spectrophotometer.

\section{PCR amplification and gel electrophoresis}

In order to determine the nucleotide sequence of coat protein of blackgram yellow mosaic virus, specific primers available in the literature were tried to amplify coat protein region of yellow mosaic viruses of nearly 1000 bp. Primers specific to MYMV (MYMV-CP-F-ATG GG (T/G) TCC GTT GTA TGC TTG / MYMV-CP-R-GGC GTC ATT AGC ATA GGC AAT) were used for amplification of coat protein gene of Blackgram yellow mosaic virus (BGYMV). Primers were designed to get the complete coat protein gene of yellow mosaic viruses of legume hosts by taking 100 extra nucleotides on both the sides of the gene (Naimuddin and Mohd. Akram, 2010).

PCR was performed in Thermocycler (Eppendorf Mastercycler gradient, Hamburg, Germany) programmed for one step of initial denaturation at $94^{\circ}$ for 2 min and 35 cycles of denaturation at $94^{\circ} \mathrm{C}$ for $1 \mathrm{~min}$, annealing at $55^{\circ} \mathrm{C}$ for $2 \mathrm{~min}$ for primers MYMV-CP-F/ MYMV-CP-R and extension at $72^{\circ} \mathrm{C}$ for 3 min, followed by one step of final extension at $72^{\circ} \mathrm{C}$ for $10 \mathrm{~min}$. PCR was conducted with Dream Taq Master mix (Fermentas) in total reaction mixture volume of $25 \mu \mathrm{l}$ that contained Dream Taq Master mix- $13 \mu \mathrm{l}$; $\mathrm{dH} 2 \mathrm{O}-4 \mu \mathrm{l}$; forward and reverse primers (20 pmole/ $\mu \mathrm{l}$ )- $2 \mu \mathrm{l}$ each; DNA template (total nucleic acid-100ng/ $\mu$ l)- $4 \mu \mathrm{l}$, and. PCR products were subjected to electrophoresis in 1 $\%$ agarose at $50 \mathrm{~V}$ for 45 minutes in Electrophoresis system - SCOTLAB (Anachem Ltd.) in Tris-acetate- EDTA buffer containing ethidium bromide @ $0.1 \%$. The gel was observed under Gel Documentation System (IMAGO Compact Imaging System, B \& L Systems, Isogen Lifescience, The Netherlands).

\section{Cloning and sequencing of coat protein} gene of YMV infecting mungbean

The PCR products were purified from agarose gel using Qiagen Gel Extraction kit (Qiagen, Hilder, Germany). All amplicons were cloned into the plasmid vector pTZ57R/T using InsTAclone ${ }^{\mathrm{TM}}$ PCR Cloning Kit following the manufacturer's instructions. Transformed colonies were screened and selected on LB agar medium amended with ampicillin, X-gal and IPTG. Isolated plasmids from transformed positive clones were confirmed for the presence of insert using the respective $\mathrm{CP}$ specific primers. The resultant positive clones were fully sequenced in both directions using universal M13 forward and reverse primers. Full length sequence of coat protein of YMV 
was obtained by aligning of forward and reverse reaction sequences.

Phylogenetic analysis, nucleotide sequence and amino acid sequence comparison of coat protein gene of yellow mosaic virus of urdbean with other geminiviruses

Pairwise and multiple sequence alignment of the full length of coat protein sequence of various YMV was done using MEGA 5.1 multiple alignment tool. The phylogenic neighbor-joining trees and evolutionary analysis were conducted using MEGA 5.1 software package (Tamura et al., 2007) based on coat protein gene sequences of MYMV with 21 other geminivirus sequences downloaded from NCBI Genbank (Table 1). Robustness of trees was determined by bootstrap sampling of multiple sequence alignment with 1000 replications. Comparision of the nucleotide and amino acid sequences of YMV was analysed by using sequence identity matrix tool of Bio-Edit software (Version 7.9.1).

\section{Results and Discussion}

Young leaves showing characteristic yellow mosaic symptoms were collected from field infected urdbean plants and used total DNA was isolated according to Rouhibaksh et al. (2008). DNA from healthy plants was also isolated. Total DNA was used as template in PCR reactions. A set of degenerate primers specific to coat protein region of MYMIV (NM1/NM2), MYMV (MYMV-CPF/ MYMV-CP-R) available in the literature were synthesized.

Polymerase chain reaction of yellow mosaic virus infecting blackgram samples using MYMV-CP-F/MYMV-CP-R primers amplified the expected product of size 1000 bp from blackgram infected samples. PCR products from the yellow mosaic affected samples of blackgram when analysed on gel, yielded an amplicon of expected size of nearly 1000 bp (Plate 2). But no amplicon was observed in PCR products from healthy plants indicating no infection by MYMV in plants that were free from yellow mosaic symptoms. No amplification of PCR products was observed with NM1/NM2 primers which were highly specific to MYMIV, suggesting that yellow mosaic virus infecting blackgram in Bangalore is an isolate of MYMV but not MYMIV. Expected PCR products of size 1000 bp obtained were cloned, sequenced and assembled. The total number of sequences obtained from blackgram yellow mosaic was 880 bp with 106 bp of pre-coat protein region and $774 \mathrm{bp}$ of coat protein region of blackgram yellow mosaic virus. 257 amino acid lengths were predicted after translation of the nucleotide sequences. The complete nucleotide sequence of the $\mathrm{CP}$ gene of BGYMV, Hebbal, Bangalore isolate had single open reading frame (ORF) of 774 base pairs and 257 amino acids.

The cluster phylogram based on pairwise and multiple sequence alignment of the nucleotide sequence of the CP gene of 8 isolates of MYMV and 13 isolates of MYMIV indicated that the present isolate causing blackgram yellow mosaic virus formed cluster with other known isolates of MYMV. The present isolate clustered with MYMV-Maharashtra, MYMVTamil Nadu, MYMVMadurai and MYMVNammakal isolates infecting soybean, mungbean, soybean and mothbean respectively (Fig. 1).

Sequence comparisons indicated that BGYMV has the highest nucleotide sequence identity of about 98.7 per cent, 98.4 per cent and 98.3 per cent and with MYMV-Namakkal:MoB [DQ865201.1]; MYMV-Madurai:SB [AJ421642.1], MYMV-Tamil Nadu:MB [AJ132575.1] and MYMV-Maharashtra:SB [AF314530.1] isolates, respectively (Table 2). 
The nucleotide sequence identity of BGYMV with MYMV ranged from 94.4-98.7 per cent. The nucleotide sequence identity of BGYMV with MYMIV ranged between 79-80.7 per cent. BGYMV had 80.7 per cent, 79.9 per cent and 79.8 per cent identity with MYMIVIndia:SB [AY049772.1], MYMIVPakistan:MB [AY269992.1] and MYMIVPakistan:BG [FM208845.1];MYMIVIndonesia:YLB [JN368437.1]; MYMIVBangladesh:MB [AF314145.1] isolates, respectively.

When the deduced amino acid sequence of individual proteins were compared with those of other begomoviruses, the maximum homology of 99.2 per cent and 98.8 per cent was noticed with MYMV-Tamil Nadu:MB [AJ132575.1]; MYMV-Maharashtra:SB [AF314530.1] and MYMV-Namakkal:MoB [DQ865201.1]; MYMV-Madurai:SB [AJ421642.1] isolates, respectively (Table 2). The deduced amino acid identities of BGYMV with Mungbean yellow mosaic virus revealed identities between 99.2-95.7 per cent. BGYMV shared 99.2 per cent homology with MYMV-Tamil Nadu:MB [AJ132575.1], MYMV-Maharashtra:SB [AF314530.1] and 98.8 per cent with MYMV-Namakkal: MoB[DQ865201.1]; MYMV-Madurai:SB [AJ421642.1] isolates. Deduced amino acid sequence comparison revealed that BGYMV revealed identities ranged from 84-85.9 per cent with Mungbean yellow mosaic India virus at amino acid level. BGYMV showed 85.9 per cent homology with MYMIVPalampur:FB [FN794200.1], MYMIVJabalpur:SB [AJ416349.1] and MYMIVPakistan:MB [AY269992.1]. 85.6 per cent homology was obtained with MYMIVVaranasi:Do [AY547317.1], MYMIVIndia:SB [AY049772.1] and MYMIVPakistan:BG [FM208845.1] isolates. The results from the phylogenetic analysis, nucleotide sequence identity and amino acid identity confirmed that blackgram yellow mosaic virus from Bangalore is an isolate of MYMV.

Phylogenetic tree based on full length of coat protein gene sequences of four isolates of blackgram yellow mosaic virus with other isolates formed two major clusters of MYMIV and MYMV. The four clusters formed unique cluster with MYMIV group that cause yellow mosaic disease symptoms MYMIV group that cause yellow mosaic disease symptoms in blackgram (AF126406), mungbean (AY271893), soybean (DQ389146) and cowpea (DQ389153). The nucleotide sequence analysis of the four blackgram isolates infected by yellow mosaic virus with other geminivirus sequences showed that YMV isolate had $>92$ per cent homology with MYMIV and less than 80 per cent homology with MYMV, MSV, BGYMV, ToLCV, DoYMV and HgYMV. A comparison of predicted amino acid sequence of coat protein gene of four isolates blackgram yellow mosaic virus from Andhra Pradesh with other amino acid sequences indicated that YMV had $>92$ per cent homology with MYMIV and less than 66 per cent homology with all other geminiviruses (Obaiah, 2011). The results obtained are in conformity with earlier investigations carried out by Naimuddin and Mohd. Akram (2010), Kamaal Naimuddin et al. (2011), Mohammad Nurul Islam et al. (2012), Naimuddin and Akram (2012) and Sachan Mansi et al. (2010).

Coat protein genes have traditionally proven useful for plant virus identification and classification. Because of its high degree of conservation, the coat protein ORF (CP or AV1) is the only begomovirus sequence approved by the International Committee on Taxonomy of Viruses for ascertaining the identity of a begomovirus (Mayo and Pringle, 1998), and the sequence comparison has been used to identify and classify geminiviruses (Malla Padidam et al., 1995; Brown et al., 
2001).The CP gene is the sole structural protein of geminiviruses and has been shown to play a determinative role in the transmission of the viruses (Pradeep Sharma et al., 2005). The CP gene is the most highly conserved gene in the family Geminiviridae. These sequences which effectively predicts discrete strains, species and taxonomic lineage of begomoviruses, has been accepted by ICTV as desirable marker for virus identity when full length genomic sequences are not available (Rybicki et al., 1998). The utility of the $\mathrm{CP}$ gene sequences for these purposes is likely possible because the $\mathrm{CP}$ sequences are optimally average variable and conserved regions to arrive at a prediction more in line with extent of sequence variation and conservation across the entire genome (Brown et al., 2001).

As per the latest guidelines if nucleotide identity at coat protein sequence is $>90 \%$, it will be considered as variant, strain or isolate of the same virus and $<90 \%$ will be considered as distinct species in begomovirus classification (Fauquet et al., 2008). The International Committee on Taxonomy of Viruses (ICTV) accepts the classification of begomoviruses based on $\mathrm{CP}$ gene sequences, when full length sequences are not available (Rybicki et al., 1998). Member of the genus Begomovirus are known to form clusters according to geographical origin with distinct branches for viruses from America, Africa and Asia. The results of the phylogenetic analysis, nucleotide sequence comparison and amino acid sequence comparison of the present study revealed that coat protein gene of yellow mosaic virus infecting blackgram (BGYMVHebbal-Bangalore) is a Mungbean yellow mosaic virus (MYMV) but not Mungbean yellow mosaic India (MYMIV) virus and it is a variant of mungbean yellow mosaic virus since it showed 94.4-98.7 per cent identity at nucleotide level with other MYMV isolates.

Plate.1 Urdbean plants showing typical symptoms of yellow mosaic virus

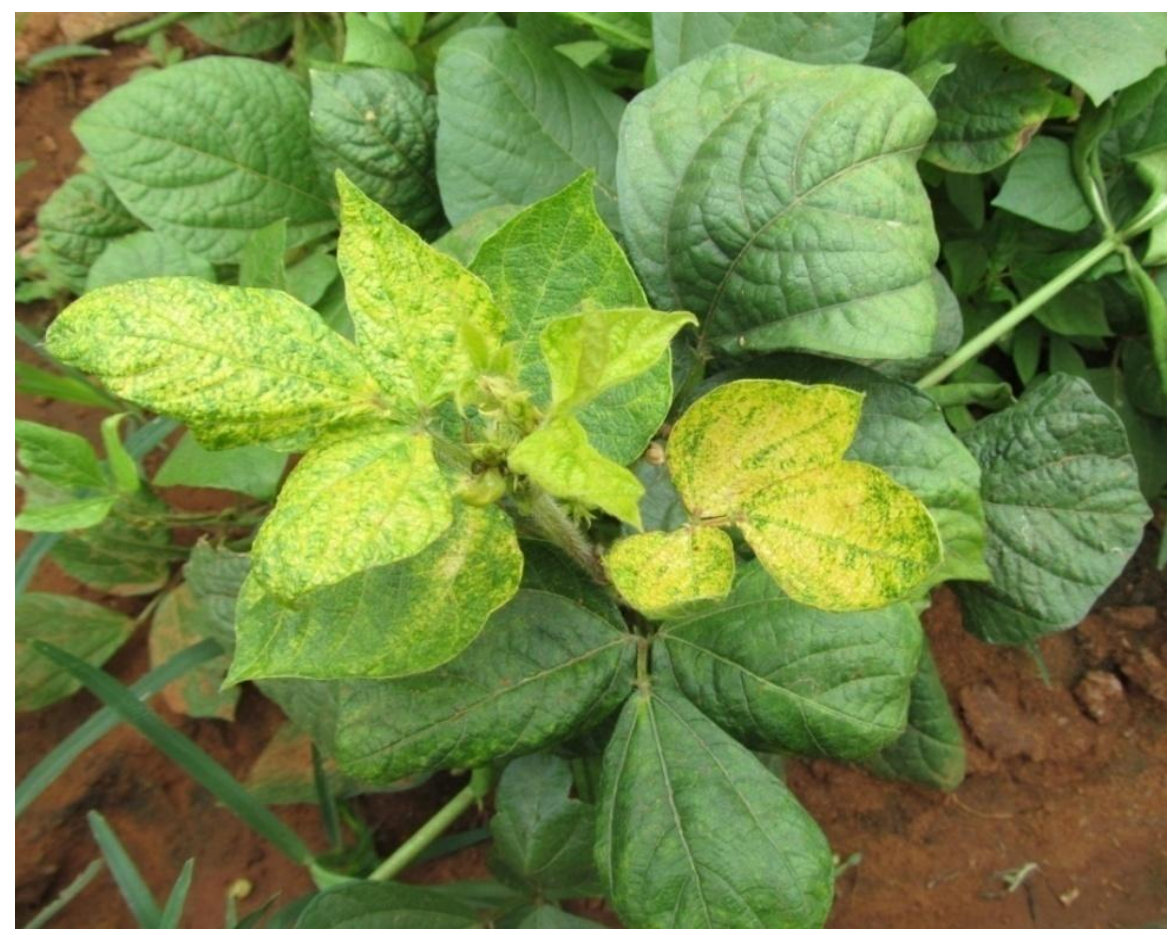


Table.1 List of geminiviruses used for comparison of coat protein gene sequences, their origin, host species and NCBI accession numbers

\begin{tabular}{|c|c|c|c|c|c|}
\hline $\begin{array}{l}\text { Sl. } \\
\text { No. }\end{array}$ & Virus species & Abbreviation & $\begin{array}{l}\text { Geographical } \\
\text { origin }\end{array}$ & Host species & $\begin{array}{l}\text { Accession } \\
\text { number }\end{array}$ \\
\hline 1. & Mungbean yellow mosaic virus & MYMV-Haryana:MB & Haryana & $\begin{array}{l}\text { Mungbean } \\
\text { (MB) }\end{array}$ & AY271896.1 \\
\hline 2. & Mungbean yellow mosaic virus & $\begin{array}{l}\text { MYMV- } \\
\text { Namakkal:MoB }\end{array}$ & Namakkal & $\begin{array}{l}\text { Mothbean } \\
(\mathrm{MoB})\end{array}$ & DQ865201.1 \\
\hline 3. & Mungbean yellow mosaic virus & MYMV:Combodia:MB & Combodia & $\begin{array}{l}\text { Mungbean } \\
\text { (MB) }\end{array}$ & AY271892.1 \\
\hline 4. & Mungbean yellow mosaic virus & MYMV-Madurai:SB & Madurai & Soybean (SB) & AJ421642.1 \\
\hline 5. & Mungbean yellow mosaic virus & MYMV-Pakistan:SB & Pakistan & Soybean (SB) & AY269991.1 \\
\hline 6. & Mungbean yellow mosaic virus & $\begin{array}{l}\text { MYMV- } \\
\text { Maharashtra:SB }\end{array}$ & Maharashtra & Soybean (SB) & AF314530.1 \\
\hline 7. & Mungbean yellow mosaic virus & MYMV-Thailand:MB & Thailand & $\begin{array}{l}\text { Mungbean } \\
\text { (MB) }\end{array}$ & AB017341.1 \\
\hline 8. & Mungbean yellow mosaic virus & $\begin{array}{l}\text { MYMV-Tamil } \\
\text { Nadu:MB }\end{array}$ & Tamil Nadu & $\begin{array}{l}\text { Mungbean } \\
\text { (MB) }\end{array}$ & 575.1 \\
\hline 9. & $\begin{array}{l}\text { Mungbean yellow mosaic } \\
\text { India virus }\end{array}$ & MYMIV-Indonesia:SB & Indonesia & Soybean (SB) & JN368438.1 \\
\hline 10 & $\begin{array}{l}\text { Mungbean yellow mosaic } \\
\text { India virus }\end{array}$ & MYMIV-Akola:MB & Akola & $\begin{array}{l}\text { Mungbean } \\
\text { (MB) }\end{array}$ & AY271893.1 \\
\hline 11 & $\begin{array}{l}\text { Mungbean yellow mosaic } \\
\text { India virus }\end{array}$ & MYMIV-India:SB & India & Soybean (SB) & AY049772.1 \\
\hline 12 & $\begin{array}{l}\text { Mungbean yellow mosaic } \\
\text { India virus }\end{array}$ & $\begin{array}{l}\text { MYMIV- } \\
\text { Indonesia:YLB }\end{array}$ & Indonesia & $\begin{array}{l}\text { Yard long } \\
\text { bean (YLB) }\end{array}$ & JN368437.1 \\
\hline 13 & $\begin{array}{l}\text { Mungbean yellow mosaic } \\
\text { India virus }\end{array}$ & MYMIV-Pakistan:BG & Pakistan & $\begin{array}{l}\text { Blackgram } \\
(\mathrm{BG})\end{array}$ & FM208845.1 \\
\hline 14 & $\begin{array}{l}\text { Mungbean yellow mosaic } \\
\text { India virus }\end{array}$ & MYMIV-Pakistan:MB & Pakistan & $\begin{array}{l}\text { Mungbean } \\
\text { (MB) }\end{array}$ & AY269992.1 \\
\hline 15 & $\begin{array}{l}\text { Mungbean yellow mosaic } \\
\text { India virus }\end{array}$ & $\begin{array}{l}\text { MYMIV- } \\
\text { Indonesia:YLB }\end{array}$ & Indonesia & $\begin{array}{l}\text { Yard long } \\
\text { bean (YLB) }\end{array}$ & JN368434.1 \\
\hline 16 & $\begin{array}{l}\text { Mungbean yellow mosaic } \\
\text { India virus }\end{array}$ & $\begin{array}{l}\text { MYMIV- } \\
\text { Indonesia:YLB }\end{array}$ & Indonesia & $\begin{array}{l}\text { Yard long } \\
\text { bean (YLB) }\end{array}$ & JN368432.1 \\
\hline 17 & $\begin{array}{l}\text { Mungbean yellow mosaic } \\
\text { India virus }\end{array}$ & MYMIV-Nepal:MB & Nepal & $\begin{array}{l}\text { Mungbean } \\
\text { (MB) }\end{array}$ & AY271895.1 \\
\hline 18 & $\begin{array}{l}\text { Mungbean yellow mosaic } \\
\text { India virus }\end{array}$ & MYMIV-Varanasi:Do & Varanasi & $\begin{array}{l}\text { Fieldbean } \\
\text { (Do) }\end{array}$ & AY547317.1 \\
\hline 19 & $\begin{array}{l}\text { Mungbean yellow mosaic } \\
\text { India virus }\end{array}$ & $\begin{array}{l}\text { MYMIV- } \\
\text { Bangladesh:MB }\end{array}$ & Bangladesh & $\begin{array}{l}\text { Mungbean } \\
\text { (MB) }\end{array}$ & AF314145.1 \\
\hline 20 & $\begin{array}{l}\text { Mungbean yellow mosaic } \\
\text { India virus }\end{array}$ & MYMIV-Jabalpur:SB & Jabalpur & Soybean (SB) & AJ416349.1 \\
\hline 21. & $\begin{array}{l}\text { Mungbean yellow mosaic } \\
\text { India virus }\end{array}$ & MYMIV-Palampur:FB & Palampur & $\begin{array}{l}\text { Frenchbean } \\
\text { (FB) }\end{array}$ & FN794200.1 \\
\hline
\end{tabular}


Table.2 Nucleotide and amino acid sequence identities of coat protein gene of yellow mosaic virus infecting blackgram with other geminiviruses

\begin{tabular}{|c|c|c|c|c|}
\hline $\begin{array}{l}\text { Sl. } \\
\text { No. }\end{array}$ & $\begin{array}{l}\text { Accession } \\
\text { number }\end{array}$ & Sequences & $\begin{array}{c}\text { Nucleotide sequence } \\
\text { identity }\end{array}$ & $\begin{array}{c}\text { Amino acid } \\
\text { sequence identity }\end{array}$ \\
\hline 1. & AY271896.1 & MYMV-Haryana:MB & 94.4 & 95.7 \\
\hline 2. & DQ865201.1 & MYMV-Namakkal:MoB & 98.7 & 98.8 \\
\hline 3. & AY271892.1 & MYMV:Combodia:MB & 96.3 & 97.2 \\
\hline 4. & AJ421642.1 & MYMV-Madurai:SB & 98.7 & 98.8 \\
\hline 5. & AY269991.1 & MYMV-Pakistan:SB & 94.8 & 96.4 \\
\hline 6. & AF314530.1 & MYMV-Maharashtra:SB & 98.3 & 99.2 \\
\hline 7. & $\mathrm{AB} 017341.1$ & MYMV-Thailand:MB & 96.6 & 98.0 \\
\hline 8. & AJ132575.1 & MYMV-Tamilnadu:MB & 98.4 & 99.2 \\
\hline 9. & JN368438.1 & MYMIV-Indonesia:SB & 79.7 & 84.0 \\
\hline 10. & AY271893.1 & MYMIV-Akola:MB & 79.0 & 84.4 \\
\hline 11. & AY049772.1 & MYMIV-India:SB & 80.7 & 85.6 \\
\hline 12. & JN368437.1 & MYMIV-Indonesia:YLB & 79.8 & 85.2 \\
\hline 13. & FM208845.1 & MYMIV-Pakistan:BG & 79.8 & 85.6 \\
\hline 14. & AY269992.1 & MYMIV-Pakistan:MB & 79.9 & 85.9 \\
\hline 15. & JN368434.1 & MYMIV-Indonesia:YLB & 79.7 & 84.4 \\
\hline 16. & JN368432.1 & MYMIV-Indonesia:YLB & 79.7 & 84.8 \\
\hline 17. & AY271895.1 & MYMIV-Nepal:MB & 79.3 & 85.2 \\
\hline 18. & AY547317.1 & MYMIV-Varanasi:Do & 79.3 & 85.6 \\
\hline 19. & AF314145.1 & MYMIV-Bangladesh:MB & 79.8 & 84.0 \\
\hline 20. & AJ416349.1 & MYMIV-Jabalpur:SB & 79.5 & 85.9 \\
\hline 21. & FN794200.1 & MYMIV-Palampur:FB & 79.5 & 85.9 \\
\hline
\end{tabular}




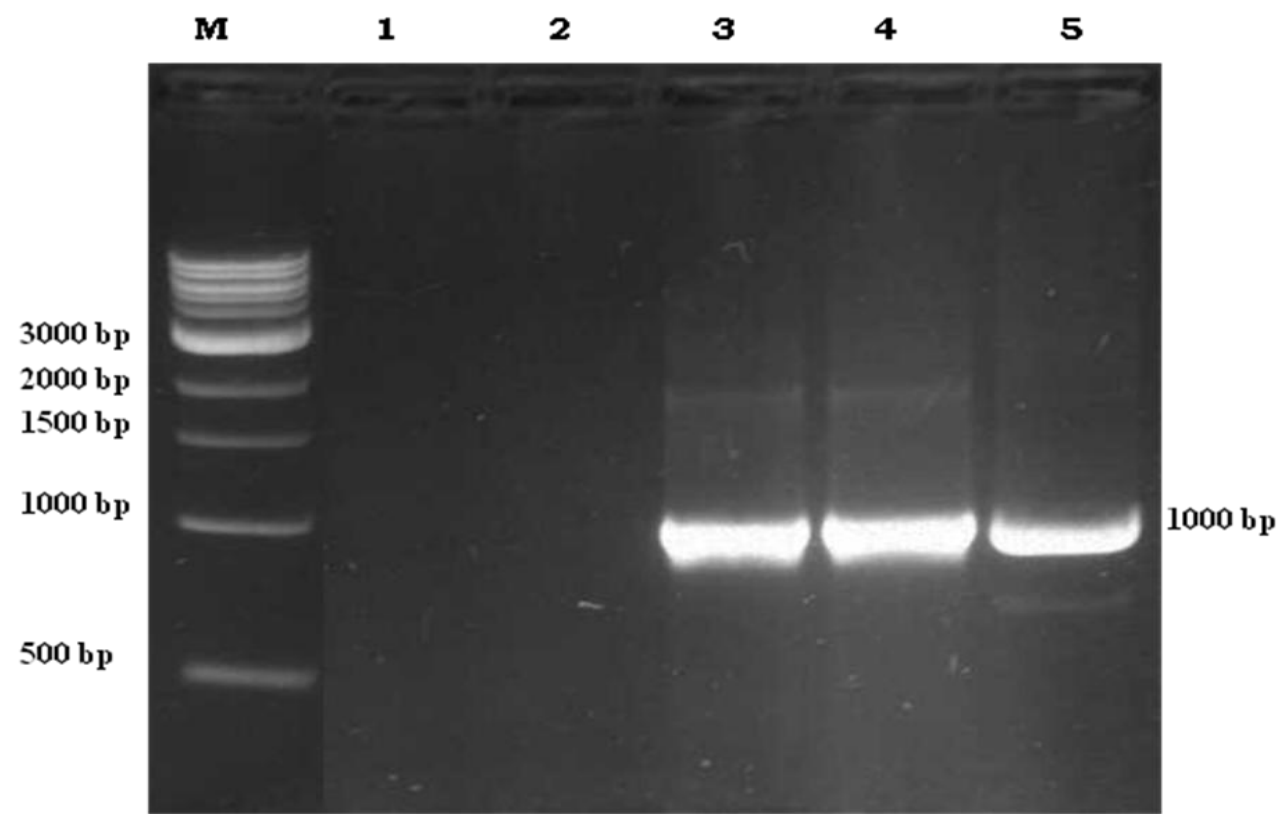

Plate.2 Amplification of coat protein gene of YMV infecting urdbean using MYMV-CPF/MYMV-CP-R primer pair

Lane:

M- $1 \mathrm{~Kb}$ Marker (NEB $1 \mathrm{~kb}$ DNA ladder)

Lane 1 -Healthy urdbean plant DNA

Lane 2 - Water control

Lane 3, 4, 5 - Specific PCR product of 1000 bp from from BGYMV infected sample

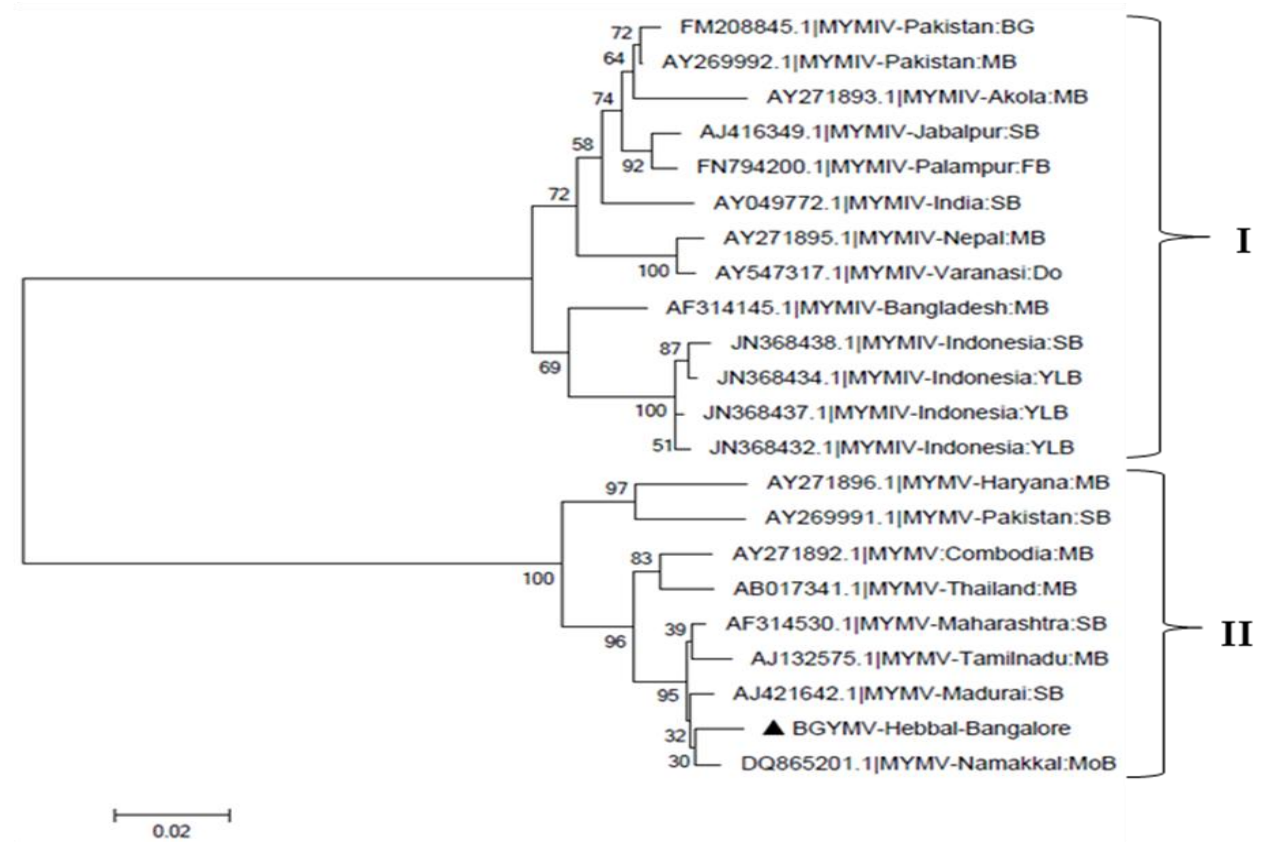

Figure.1 Phylogenetic tree obtained from comparison of complete nucleotide sequence of coat protein gene of BGYMV with other geminiviruses from database. The dendrograms are calculated using neighbor-joining algorithm of MEGA 5.1 version. Numbers at nodes indicate percentage bootstrap confidence scores $(1,000$ replications) 


\section{References}

Anonymous, 2012, Selected state wise Area, Production and Productivity of Moong (Kharif and Rabi) in India, Ministry of Agriculture and Farmers Welfare. Govt. of India.

Biswas, K. K., Tarafdar, A., and Biswas, K., 2012, Viral diseases and its mixed infection in mungbean and urdbean: Major biotic constraints in production of food pulses in India. In Asha Sinha, Sharma, B. K. and Manisha Srivastava (Eds.), Modern trends in microbial biodiversity of natural ecosystem (pp. 301-317). New Delhi: Biotech Books.

Bos L., 1999, Plant Viruses: Unique and Intriguing Pathogens: A Text Book of Plant Virology, Backhuys Publishers, The Nether-lands, 305-306.

Brown, J. K., Idris, A. M., Torres-Jerez, I., Banks, G. K. and Wyatt, S.D., 2001, The core region of coat protein gene is highly useful for establishing the provisional identification and classification of begomoviruses. Arch. Virol., 146: 1581-1598.

Fauquet, C. M., Briddon, R. W., Brown, J. K., Moriones, E., Stanley, J. and Zerbini, M., 2008, Geminivirus strain demarcation and nomenclature. Arch. Virol., 153: 783-821.

Ilyas, M., Qazi, J., Mansoor, S. and Briddon, R. W., 2010, Genetic diversity and phylogeography of begomoviruses infecting legumes in Pakistan. J. Gen. Virol., 91: 2091-2101.

Islam, M. N., Sony, S. K. and Borna, R. S., 2012, Molecular characterization of Mungbean yellow mosaic disease and coat protein gene in mungbean varieties of Bangladesh. Pl. Tissue Cult. Biotech., 22: 73-81.

Kamaal Naimuddin, Mohammad Akram and Gupta Sanjeev, 2011, Identification of Mungbean yellow mosaic India virus infecting Vigna mungo var. silvestris L. Phytopathol. Mediterr., 50: 94-100.

Malathi, V. G. and John, P., 2008, Gemini viruses infecting legumes. In G. P. Rao, P. L. Kumar, \& R. J. HolguinPeña (Eds.), Vegetable and pulse crops: Vol. 3. Characterization, diagnosis and management of plant viruses (pp. 97-123). USA: Studium Press LLC.

Malla Padidam, Roger, N. Beachy and Claude, M. Fauquet, 1995, Classification and identification of geminiviruses using sequence Comparisons. J. Gen. Virol., 76: 249263.

Mayo, M.A. and Pringle, C.R., 1998, Virus taxonomy-1997. J. Gen. Virol., 79: 649-657.

Mohammad Nurul Islam, Sonia Khan Sony and Rita Sarah Borna, 2012, Molecular characterization of mungbean yellow mosaic disease and coat protein gene in mungbean varieties of Bangladesh. Pl. Tissue Cult. Biotech., 22: 73-81.

Naimuddin and Mohd. Akram, 2010, Detection of mixed infection of begomoviruses in cowpea and their molecular characterization based on CP gene sequences. J. Food Legumes, 23: 191-195.

Naimuddin and Akram, M., 2012, Sequence comparison of coat protein gene of Mungbean yellow mosaic India virus isolates infecting mungbean and urdbean crops. J. Food Legume, 25: 286-290.

Nene Y.L., 1972, A survey of viral diseases of pulse crops in Uttar Pradesh, Uttar Pradesh Agricultural University, Pantnagar, Research Bulletin No. 4, 191.

Nene, Y. L., 1972, A study of viral disease of pulse crops in Uttar Pradesh. Res. Bull. No.4., G. B. Pant. Univ. Agri. 
Tech., Pantnagar, 144 pp.

Obaiah, S., 2011, Molecular detection and characterization of yellow mosaic virus infecting blackgram in Andhra Pradesh. M. Sc. (Agri.) Thesis, Acharya N.G. Ranga Agri. Univ., Hyderabad, 99pp.

Pradeep Sharma., Narayan Rishi. and Malathi, V. G., 2005, Molecular cloning of coat protein gene of an Indian cotton leaf curl virus (CLCuV-HS2) isolate and its phylogenetic relationship with other members of geminiviridae. Virus Genes, 30: 85-91.

Qazi, J., Ilyas, M., Mansoor, S. and Briddon, R. W., 2007, Legume yellow mosaic viruses: Genetically isolated begomoviruses. Mol. Pl. Pathol., 8: 343-348.

Rathi Y.P.S., 2002, Epidemiology, yield losses and manage-ment of major diseases of Kharif pulses in India, Plant Pathology and Asian Congress of Mycology and Plant Pathology, University of Mysore, Mysore, India.

Roger Hull, 2004, Mathew's Plant Virology, 4th ed., Elsevier Pub-lishers, India, 180-182.

Rouhibakhsh, A., Priya, J., Periasamy, A., Haq, Q. M. I. and Malathi, V. G., 2008, An improved DNA isolation method and PCR protocol for efficient detection of multicomponents of begomovirus in legumes. $J$. Virological Methods, 147: 37-42.

Rybicki, E.P., 1998. A proposal for naming geminiviruses: A reply by the Geminiviridae study group chair. Arch. Virol., 143: 421-424.

Sachan Mansi, Mishra Minakshi, Naimuddin and Akram Mohd., 2010, amino acid variability in coat protein gene of Mungbean Yellow Mosaic India Virus infecting pulse crops. Trends Biosci., 3: 166-168.

Shad, N., Mughal, S.M. and Bashir, M., 2005, Transmission of mungbean yellow mosaic Begomovirus (MYMV). Pakistan. J. Phytopathol., 17(2): 141143.

Shahid, M. S., Ikegami, M. and Natsuaki, K. T., 2012, First report of Mungbean yellow mosaic India virus on lima bean affected by yellow mosaic disease in Nepal. Australasian Pl. Dis. Notes., 7: 85-89 .

Singh G., Singh K., Gill A.S. and Chhabra K.S., 1980, Screening for sources of resistance to yello mosaic virus of mung bean. Vigna radiate L. Wilczek. National Seminar on Disease Resistance in Crop Plants. Tamil Nadu Agricultural University, Coimbatore, 72-76.

Singh, R. A., Rajib K. D. E., Gurha, S. N and Ghosh, A., 2002, Yellow mosaic of mung bean and urd bean. IPM system in Agriculture, 8: 395-408.

Tamura, K., Dudley, J., Nei, M. and Kumar, S., 2007, MEGA4: Molecular Evolutionary Genetics Analysis (MEGA) software version 4.0. Mol. Biol. Evol., 24: 1596-1599.

Tsai, W. S., Shih, S. L., Rauf, A., Safitri, R., Hidayati, N., Huyen, B. T. T., 2013, Genetic diversity of legume yellow mosaic begomoviruses in Indonesia and Vietnam. Annals of Appl. Biol., 163: 367-377.

\section{How to cite this article:}

Prema, G.U. and Rangaswamy, K.T. 2018. Molecular Characterization of Coat Protein Gene of Blackgram Yellow Mosaic Virus (BGYMV) from Karnataka, India. Int.J.Curr.Microbiol.App.Sci. 7(07): 2225-2235. doi: https://doi.org/10.20546/ijcmas.2018.707.261 